\title{
Customer Satisfaction and Retention in Nepalese Telecom Companies
}

\author{
Dr. Prakash Shrestha \\ Lecturer, Nepal Commerce Campus, Faculty of Management, Tribhuvan University, Nepal
}

\begin{abstract}
The purpose of this research is to investigate the relationship between customer satisfaction and customer retention with special regard to Nepal's telecom industry. Data was collected through a field survey of Telecom customers in five major districts of Nepal (including Bhaktapur, Kathmandu, Lalitpur, Kaski, and Kavre). A total of 500 questionnaires were distributed to the service users of NTC and Ncell. 78.20 percent usable responses were obtained. For calculating the responses a five-point Likert scale was used. The result shows that the overall degree of customer satisfaction is sufficient across all measurements. It also shows that the customer retention level is both acceptable and satisfactory. The findings also show that all customer satisfaction dimensions in terms of product quality, price structure, service delivery, and staff attitude have a significant and positive relationship with customer retention. Our companies need to focus on their customer satisfaction and retention to keep their business successful in this highly competitive environment. The results of this study are helpful to strike our companies to pay attention to the issues of customer satisfaction and retention.
\end{abstract}

Keywords: Customers, Relationship, Retention, Satisfaction, Telecom

DOI: $10.7176 / \mathrm{EJBM} / 12-27-15$

Publication date:September $30^{\text {th }} 2020$

\section{Introduction}

Any business organization's success depends on customers, their satisfaction, and their effectiveness in maintaining them. Customer satisfaction means that the needs of consumers are addressed, that their concerns are treated, and that they are pleased with their experience of the business and its products or services. It makes customers happy (Shrestha, 2019). Customer retention applies to the case of consumers returning to the company after their first transaction and continuing to buy on a regular basis. These two dimensions coincide. Making sure consumers are pleased and satisfied with their service is the reason for them to return to the business and invest more money. There is a strong relationship between customer satisfaction and retention, where the building and retaining a loyal customer base is a key strategy (Ennew, Binks, \& Chiplin, 2015). Hansemark and Albinsson (2004) have also argued a clear link between these two aspects of the relationship approach to marketing.

A big trend in marketing research is customer retention. It has become an important business issue and a strategic focus for many. This growing concern has been due mainly to intense competition, particularly in the service industries (Al-Msallam, 2015). Building a mutually beneficial relationship between customers and companies is considered the core of the relational marketing approach in recent times. This concept is also applicable in the case of our telecom business. In the case of Nepal, we have Nepal Telecom (NTC) and Ncell. They are the major two telecommunication companies that are playing the dominant role to serve their subscribers in the Nepalese market. Few other Cellular Network Provider companies are emerging steadily side by side. All these telecommunications companies focus on acquiring customers and retaining existing customers.

In a study, Lee and Freick (2001) noted that in the cellular phone industry, customer retention is very critical, as operators lose about 20 percent or more of their customers each year, and have high customer acquisition expenses. So, it is critical for telecom companies to build well-designed and customer retention programs to sustain their business. Yankee (2001) suggested that the total cost of attracting new customers for maintaining current customers is approximately seven times higher for Cellular operators. Telecom companies usually find it inexpensive to maintain their customer base in a complex technological setting, rather than to model strategies to obtain them. Zeithamal and Bitner (1996) identified the determinants that would impact customer satisfaction, such as price, call quality, perceptions, values, network coverage, and availability of networks. The study of the relationship between loyalty, retention, and profitability has received particular attention (Dawkins \& Reichheld, 1990; Reichheld \& Sasser, 1990; Gerpott \& Schindler, 2001; Kim \& Yoon, 2004). These studies have specifically sought 
to examine the determinants of customer loyalty that, for example, help telecommunications companies retain their client base. This paper is, therefore, aimed at exploring the relationship between customer satisfaction and customer retention that integrates the case of Nepalese telecom companies.

\section{Objectives of the Study}

The purpose of this research is to investigate the relationship between customer satisfaction and customer retention with special regard to Nepal's telecom industry.

\section{Literature Review}

\subsection{Customer Satisfaction}

One significant aspect of this study is customer satisfaction. It refers to serving and fulfilling people with their requirements (Shrestha, 2018). Customer satisfaction is the feeling of gratification or dissatisfaction of an individual as a result of comparing the perceived output or outcome of a product with respect to his or her expectations (Kotler \& Keller, 2012). It refers to how happy customers are with an organization's products. A high level of customer satisfaction is very important for the organization because happy customers are more likely to be dedicated and repeat orders and use a wide variety of the organization's products (Shrestha, 2018). Various researches established the benefits of customer satisfaction (e.g. Crosby, Evans, \& Cowles, 1990; Storbacka, Strandvik, \& Gronroos, 1994; Fisher, 2001; Caruana, 2002; Arokiaswamy 2013; Jiana, 2015; Kumar, 2018). Most of them stated customer satisfaction is a cognitive and affective measure of consumers based on their personal experience across all episodes of service within the relationship. Customers get such total satisfaction with all the transactions and experiences. It is a cognitive and affective assessment of consumers based on their personal experience across all the services. Customer satisfaction is an overall measure of a product or service based on the purchase experience and its use over time. The key factors which can affect customer satisfaction are service and product quality, pricing strategy, and store characteristics (Khadka \& Maharjan, 2017). However, in this study, it is assumed that product quality, price structure, service delivery, and staff attitude are the key factors that create customer satisfaction.

\subsection{Customer Retention}

Customer retention is the operation a company conducts to reduce customer defects. Good customer retention begins with the first interaction which a company has with a customer and continues throughout a relationship's entire existence. The potential of a company to attract and maintain new customers is not only related to its goods or services but is also closely linked to the way it treats its current customers and the image it builds within and outside the market. Consumer retention is more than about offering what they want to the consumer; it's about fulfilling their needs so they become loyal advocates for the business's brand. Roos (1999) said customer retention is the act of retaining customers as a result of service quality and customer satisfaction. However, companies should be interested in customer retention, for the many reasons such as to keep customers costs less than to obtain, a loyal customer would be more dedicated to the supplier they select, and around half the new customers come from recommendations made by current customers/customers (Kumar, 2000).

The interpretation and implementation of customer retention are of great importance for businesses. Various researches established the benefits of customer retention (e.g. Bolton, 1998; Mittal \& Kamakura, 2001; Verhoef 2003; Gustafsson, Johnson, \& Roos, 2005; Tamulienea \& Gabryteb, 2014). Various factors can affect customer retention. Factors including top management support, transportation costs, perceived quality of service, consumer satisfaction, customer involvement, pricing, membership, and staffing have been found to have a significant effect on every company's retention rate (Diller, 1997; Dawes \& Swailes, 1999; Reinartz and Kumar, 2003). However, in this study, it is assumed that value, consistency, communication, sincerity, relationship, trust, and switching barriers are the key factors that create customer retention.

\section{The Research Framework and Hypotheses}

For this study, a research framework was built on the basis of the above discussion. Below is the schematic diagram of the framework and research hypotheses. 


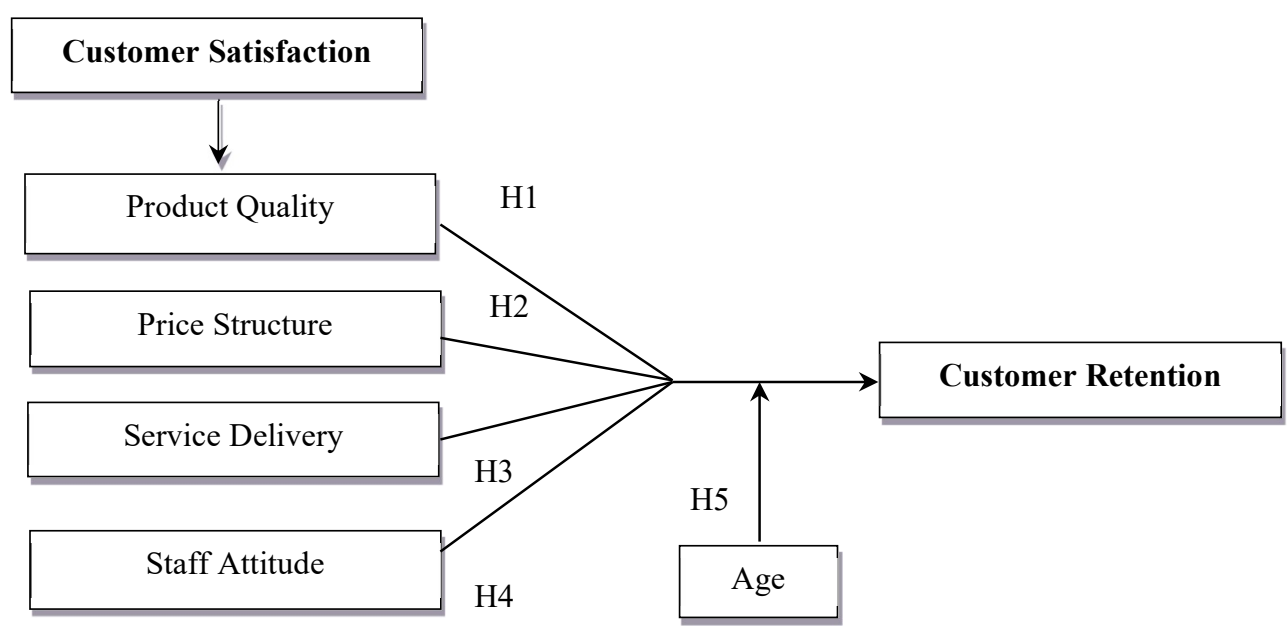

Figure 1: Research framework and hypotheses

Customer satisfaction dimensions such as product quality, price structure, service delivery, and staff attitude are the independent variables and customer retention is the dependent variable in this study. The age of customers is taken as a moderating variable in this study. This study assumes a positive relationship between customer satisfaction dimensions and customer retention. Based on this assumption the key hypotheses of the study are:

H1: $\quad$ The product quality has a favorable and significant relationship to consumer retention.

H2: $\quad$ The price structure has a favorable and significant relationship to the retention of customers.

H3: $\quad$ Service delivery has a favorable and significant association with customer retention.

H4: $\quad$ There is a strong and significant relationship between employee attitude and customer retention.

H5: Regarding customer retention, male and female customers vary significantly.

\section{Research Methods}

The population of this study is customers using the Cellular Network service in Nepal. Data was collected through a field survey of Telecom customers/users in five major districts of Nepal (including Bhaktapur, Kathmandu, Lalitpur, Kaski, and Kavre). A total of 500 questionnaires were distributed to the service users of NTC \& Ncell. Only 391 usable responses were obtained, providing an acceptable level of response rate of 78.20 percent. For calculating the responses a five-point Likert scale was used. Table 1 presents the respondent's profile.

Table 1. Respondent's profile

\begin{tabular}{lclc}
\hline Gender & Percent & Type of services & Percent \\
\hline Female & 49.40 & Pre-paid users & 60.90 \\
Male & 50.60 & Post-paid users & 39.10 \\
\hline Note: $n=391$ & & & \\
\hline
\end{tabular}

As the data analysis tools, descriptive statistics including mean and standard deviation (S.D.) were used. The relationship between the dimensions of customer satisfaction and customer retention was analyzed using multiple regression model given below:

$$
Y=\beta_{0}+\beta_{1} X_{1}+\beta_{2} X_{2}+\beta_{3} X_{3}+\beta_{4} X_{4}+e_{t}
$$

Where,

$\mathrm{Y}=$ Customer Retention

$\beta_{0}=$ Constant

$\mathrm{X}_{1}=$ Product quality

$\mathrm{X}_{2}=$ Price structure

$\mathrm{X}_{3}=$ Service delivery

$\mathrm{X}_{4}=$ Staff attitude

$\beta=$ Coefficient of each dimension

$\mathrm{e}_{\mathrm{t}}=$ Error term 


\section{Empirical Results and Discussion}

This section presents the outcome of an empirical study. First part presents the results of descriptive statistics and next part presents the regression results.

\subsection{Descriptive Statistics}

The aggregate customer satisfaction on the four key dimensions and status of customer retention are presented in Table 2 .

Table 2: Descriptive Statistics of BSC Perspective

\begin{tabular}{|c|c|c|c|c|}
\hline S. no. & Variables & Mean & S.D. & Reliability \\
\hline 1. & Product Quality & 3.51 & 0.92 & 0.79 \\
\hline 2. & Price Structure & 3.64 & 0.54 & 0.81 \\
\hline 3. & Service Delivery & 3.71 & 0.57 & 0.78 \\
\hline 4. & Staff Attitude & 3.61 & 0.61 & 0.84 \\
\hline 5. & Customer Retention & 3.79 & 0.82 & 0.83 \\
\hline
\end{tabular}

Note: $n=391$

Reliability is calculated by the Alpha value of Cronbach. The Alpha value is larger than Sekaran's (2006) argument. Thus, the instruments used to calculate these variables are reasonably accurate and give useful results.

Since all the mean values are more than average in the scale of a five-point Likert scale, the result shows that the overall customer satisfaction level and customer retention are adequate and satisfactory. In this way, Nepalese telecom companies have better performance in terms of customer satisfaction management and customer retention issues. The mean for the service delivery is found to be the highest i.e. 3.71 which implicates that the service delivery has the highest contribution to customer satisfaction in the Nepalese telecommunication sector.

\subsection{Relationship between Customer Satisfaction and Retention}

Customer retention is regarded as a dependent variable in this regression model, and four dimensions of customer satisfaction integrated into the analysis are known as independent variables. Consequently, the regression model is developed as:

Table 3: Regression Results

\begin{tabular}{|c|c|c|c|c|}
\hline Model & Coefficients & Std. Error & $\mathbf{t}$ & Sig. \\
\hline (Constant) & 41.327 & 3.943 & 7.621 & 0.00 \\
\hline Product quality & 1.871 & 0.311 & 6.753 & 0.00 \\
\hline Price structure & 1.307 & 0.321 & 4.847 & 0.00 \\
\hline Service delivery & 1.914 & 0.257 & 8.317 & 0.00 \\
\hline Staff attitude & 1.237 & 0.246 & 9.742 & 0.00 \\
\hline$R^{2}$ & 0.648 & & & \\
\hline Adjusted $R^{2}$ & 0.641 & & & \\
\hline F-Value & 90.291 & & & \\
\hline$p$-value of $F$ test & 0.00 & & & \\
\hline
\end{tabular}

Model:

Customer retention $=41.327+1.871 \mathrm{PQ}+1.307 \mathrm{PS}+1.914 \mathrm{SD}+1.237 \mathrm{SA}$

Where,

$\mathrm{PQ}=$ Product quality; PS = Price structure; SD = Service delivery; SA = Staff attitude

The F-value and the p-value are 90.291 and 0.00 respectively. Therefore, we can say that this model is significant at one percent level of significance. Hence, this model is fitted linearly. This model can explain 64.80 percent of the variation in customer retention by the dimensions of customer satisfaction.

The model provides results regarding the relationship between customer satisfaction dimensions and customer retention. The analyses reveal that all the dimensions of customer satisfaction have a significant and positive relationship with customer retention. Thus, these findings provide support for $\mathrm{H} 1, \mathrm{H} 2, \mathrm{H} 3$, and $\mathrm{H} 4$.

\subsection{Customer Retention and Gender}

The following table presents the results of the Man-Whitney U test to test the relationship between customer retention and gender. 
Table 4: Mann-Whitney U test

\begin{tabular}{lcc}
\hline Gender & $\mathrm{N}$ & Mean Rank \\
\hline Female & 193 & 101.26 \\
Male & 198 & 98.95 \\
\hline Total & 391 & \\
\hline$z$-value $=-0.474$ and Asymp. Sig. $(2$-tailed $) / p$-value $=0.537$ \\
\hline
\end{tabular}

The $\mathrm{p}$-value of the test is too high as compared to the 1 percent level of significance $(0.537>0.01)$. Hence, it shows that there is no significant difference in the customer retention between male and female customers or subscribers of the telecommunication companies of Nepal. Thus, the finding does not provide support for H5.

Table 5: Summary of Hypotheses Results

\begin{tabular}{|ll|c|c|}
\hline Hypotheses & Test & Decision \\
\hline H1: & $\begin{array}{l}\text { The product quality has a favorable and significant } \\
\text { relationship to consumer retention. }\end{array}$ & Regression Model & Accepted \\
\hline H2: & $\begin{array}{l}\text { The price structure has a favorable and significant } \\
\text { relationship to the retention of customers. }\end{array}$ & Regression Model & Accepted \\
\hline H3: & $\begin{array}{l}\text { Service delivery has a favorable and significant } \\
\text { association with customer retention. }\end{array}$ & Regression Model & Accepted \\
\hline H4: & $\begin{array}{l}\text { There is a strong and significant relationship between } \\
\text { employee attitude and customer retention. }\end{array}$ & Regression Model & Accepted \\
\hline H5: & $\begin{array}{l}\text { Regarding customer retention, male and female customers } \\
\text { vary significantly. }\end{array}$ & Mann-Whitney U & Rejected \\
\hline
\end{tabular}

\section{Conclusions}

The purpose of this study is to investigate the relationship between customer satisfaction and retention. The result shows that the overall degree of customer satisfaction is sufficient across all measurements. It also shows that the customer retention level is both acceptable and satisfactory. The findings also show that all customer satisfaction dimensions in terms of product quality, price structure, service delivery, and staff attitude have a significant and positive relationship with customer retention. These research findings are consistent with the results of many preceding studies (e.g., Storbacka, Strandvik, \& Gronroos, 1994; Bolton, 1998; Fisher, 2001; Mittal \& Kamakura, 2001; Caruana, 2002; Verhoef, 2003; Gustafsson, Johnson, \& Roos, 2005; Arokiaswamy, 2013; Jiana, 2015; Kumar, 2018; Tamulienea \& Gabryteb, 2014). Results indicate that customer satisfaction directly affects customer retention and leads customers to make repeat purchases; this confirms other studies such as Anderson and Sullivan (1993), and Rust and Zahorik (1993).

Based on the empirical results of this study, it can be concluded that the higher the level of customer satisfaction, the greater would be the customer retention. Our companies also need to focus on maintaining customer loyalty, so that they can retain their customer base effectively. This will contribute to improved organization-level performance and growth.

\section{Managerial Implications}

Customers are the key to business organizations. Without them, no company can stay in the business. It is highly essential to give more focus on customers and their satisfaction. The satisfaction of customers matters a lot in business success. Product quality, price structure, service delivery, and a positive staff attitude are important factors to enhance a higher level of customer satisfaction. Proper use of these factors is beneficial to make customers happy. Moreover, these factors also important for attracting customers and retaining them for long period. Retaining profitable customers is of great importance to every business. The factors such as top management support, transportation costs, perceived quality of service, consumer satisfaction, customer involvement, pricing, membership, and staffing lead to a higher level of customer retention. More retention of customers leads to more corporate image and more possibilities of earning profits. That is why our companies need to focus on their customer satisfaction and retention to keep their business successful in this highly competitive environment. The results of this study are helpful to strike our companies to pay attention to the issues of customer satisfaction and 
retention.

\section{References}

Al-Msallam, S. (2015). The relationship between customer satisfaction and customer loyalty in the banking sector in Syria. Journal of Marketing and Consumer Research, 7, 27-34.

Anderson, E.W., \& Sullivan, M.W. (1993). The antecedents and consequences of customer satisfaction for firms. Marketing Science, 12(2), 125-143.

Arokiasamy, A. A. (2013). The impact of customer satisfaction on customer loyalty and intentions to switch in the banking sector in Malaysia. Journal of Commerce, 5(1), 14-21.

Bolton, R.N. (1998). A dynamic model of the duration of the customer's relationship with a continuous service provider: The role of satisfaction. Marketing Science, 17 (Winter), 45-65.

Caruana, A. (2002). Service loyalty. The effects of service quality and the mediating role of customer satisfaction. European Journal of Marketing, 36(7/8), 811-828.

Crosby, L.A., Evans, K.R., \& Cowles, D. (1990). Relationship Quality in Services Selling: An Interpersonal Influence Perspective. Journal of Marketing, 54(3), 68-81.

Dawes, J., \& Swailes, S. (1999). Retention and frontiers: Issues for financial service retailers. The International Journal of Bank Marketing, vol. 17, 36-43.

Dawkins, P.M., \& Reichheld, F.F. (1990). Customer retention as a competitive weapon. Direct and Board, 14, 4247.

Diller, H. (1997). Fundamentals of marketing. Marketing ZFP, 18(2), 81-94.

Ennew C.T., Binks M.R., Chiplin B. (2015) Customer satisfaction and customer retention: An examination of small businesses and their banks in the UK. In: Wilson E., Black W. (eds) Proceedings of the 1994 Academy of Marketing Science (AMS) Annual Conference. Developments in Marketing Science: Proceedings of the Academy of Marketing Science. Springer, Cham.

Fisher, A. (2001). Winning the battle for customers. Journal of Financial Services Marketing, 6(2), 77-83.

Gerpott, T. R., \& Schindler, A. (2001). Customer retention, loyalty, and satisfaction in the German Cellular telecommunications market. Telecom Policy, 25(4), 249-269.

Gustafsson, A., Johnson, M.D., \& Roos, I. (2005). The effects of customer satisfaction, relationship commitment dimensions, and triggers on customer retention. Journal of Marketing, 69(4), 210-218.

Hansemark, O.C. and Albinsson, M. (2004). Customer satisfaction and retention: the experiences of individual employees. Managing Service Quality: An International Journal, 14 (1), 40-57.

Jiana, D. (2015). A research proposal - The relationship between customer satisfaction and customer loyalty, Johnson \& Wales University.

Khadka, K. \& Maharjan, S. (2017). Customer satisfaction and customer loyalty. Centria University of Applied Sciences, Business Management, Lahti, Finland.

Kim, H.S., \& Yoon, C.H. (2004). Determinants of subscriber churn and customer loyalty in the Korean mobile telephony market Determinants of subscriber churn and customer loyalty in the Korean mobile telephony market. Telecommunications Policy.

Kotler, P., \& Keller, K.L. (2012). Marketing management. New Delhi: Dorling Kindersley (India) Pvt. Ltd.

Kumar, R. S. (2002). Interpersonal affective influences on consumer satisfaction with products. Journal of Consumer Research, 7, 49-54.

Kumar, V.S. (2018). The Relationship between customer satisfaction and customer loyalty in commercial vehicle industry in India. International Journal of Management and International Business Studies, 8(1), 11-22.

Lee, J., \& Freick, L. (2001). The impact of switching cost on the customer satisfaction loyalty link: Cellular phone service in France. Journal of Service Marketing, 15(1), 35-48.

Mittal, V, \& Kamakura, W. (2001). Satisfaction, repurchase intent, and repurchase behavior: Investigating the moderating effects of customer characteristics. Journal of Marketing Research, 38, 131-142.

Reichheld, F.F., \& Sasser, W. (1990). Zero defections: quality comes to services. Harvard Business Review, 
September/October, 105-111.

Reinartz, W.J., \& Kumar, V. (1995). The impact of customer relationship characteristics profitable lifetime duration. Journal of Marketing, 67(1), 77-99.

Roos, I. (1999). Switching processes in customer relationships. Journal of Service Research, 2, 376-93.

Rust, R.T., \& Zahorik, A.J (1993). Customer satisfaction, customer, retention and market share. Journal of retailing, 69(2), 193-215.

Sekaran, U. (2006). Research methods for business: A skill-building approach. New York: John Wiley and Sons, Inc.

Shrestha, P. (2018). Service quality and customer satisfaction: Evidence of Nepalese banks. NCC Journal, 3(1), 121-133. https://doi.org/10.3126/nccj.v3i1.20254

Shrestha, P. (2019). Banking customer attitudes toward ATM service in Nepal. International Journal of Advances in Scientific Research and Engineering, 5(12), 88-93. DOI: 10.31695/IJASRE.2019.33652

Storbacka, K., Strandvik, R \& Gronroos, C. (1994). Managing customer relationship for profit: the dynamics of relationship quality. International Journal of Service Industry Management, 5(5), pp. 21-38.

Tamulienea, V., \& Gabryteb, I. (2014). Factors influencing customer retention: case study of Lithuanian mobile operators. Procedia - Social and Behavioral Sciences, 156, 447-451.

Verhoef, P.C. (2003). Understanding the effect of customer relationship management efforts on customer retention and customer share development. Journal of Marketing, 67, 30-45.

Yankee group (2001). Churn management in the mobile market: A Brazilian case study. Pub ID: YANL696399.

Zeithamal, A., \& Bitner, M.J. (1996). Customer contribution and roles in service delivery. International Journal of Service Industry Management, 8(3), 193-205. 